DOI: https://doi.org/10.47405/mjssh.v5i4.388

\begin{tabular}{|c|c|}
\hline 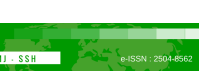 & Malaysian Journal of Social Sciences and Humanities (MJSSH) \\
\hline Malaysian Journal of & Volume 5, Issue 4, April 2020 \\
\hline (MJ . SSH) & e-ISSN : 2504-8562 \\
\hline & $\begin{array}{l}\text { Journal home page: } \\
\text { www.msocialsciences.com }\end{array}$ \\
\hline
\end{tabular}

\title{
Preparedness for the World of Work Among Malaysian Diploma Students in a Local Institution
}

\author{
Isai Amutan Krishnan', Manickavasagar Govindasamy1, Selvajothi Ramalingam1, Kausalya \\ Muthutamilselvan' ${ }^{2}$, Hee Sio Ching ${ }^{3}$ \\ 1 Faculty of Languages and Linguistics, University of Malaya (UM) \\ ${ }^{2}$ Lorong 2A/5 Taman Mutiara, Sg. Kob Karangan, Kulim, Kedah \\ ${ }^{3}$ HELP University
}

Correspondence: Isai Amutan Krishnan (amuthan.isai@gmail.com)

\begin{abstract}
The purpose of this study is to investigate the use of appraisal system-attitude and cooperative solidarity principle and also the perception of interviewees and interviewer of the job interview interactions. The data was collected in one of the local education institutions in Kuala Lumpur Malaysia. There were 20 students participated in the study. Job interviews were recorded and analysed qualitatively by using appraisal system-attitude and cooperative solidarity principle theories. Semistructured interviews as well as in-depth interview were done on the interviewees and interviewer to triangulate the study. The findings show that most of interviewees were covered the categories affect, judgment and appreciation but due to lacked English language proficiency, certain occurrences were not reflected to these categories. In relation to cooperative solidarity principle both interviewer and interviewees attribute to the interaction. The findings further reveal that most of the interviewees had difficulty in comprehending the standard interview questions and feeling nervous and anxious to answer the questions. Based on the in-depth interview with the interviewer, it was found that most of the interviewees were not able to expose to the standard interview questions and not able to understand the questions. It is hoped that the present study would be helpful for undergraduates, fresh graduates or in general job seekers as well as interviewer to carry out smooth interaction in job interviews by having better understandings on the standard interview questions.
\end{abstract}

Keywords: world of work, local institution, diploma students, job interview

\section{Introduction}

Job interview is an important genre widely used in organisational and workplace settings which serve as a strategic conversation with dual purposes about interviewer and interviewee. In addition, an evaluation and judgment can be done by employer to potential employee in term of work experience, language proficiency, professional skills, communicative effectiveness and collaborative or leadership ability, for prospective employment in their company during job interview (Hausknecht, Day \& Thomas, 2004). Furthermore, the interviewee or the interviewee can persuade the employer by their own necessary ability or skills that related to the job through job interview. In other words, a job interview allows interviewer to seek and evaluate the interviewee's ability and suitability to the organisation through standard interview questions to choose the best interviewees in applying the job through showing their respectively ability and skills during interview (Selvaratnam, 2018). 
Judgment of the candidates' competence and suitability in human resources selection and recruitment by companies and institutions through job interview has been in trend since past few decades ago (Sarangi \& Candlin, 2011; Rizvi, Teckchandany \& Ahuja, 2013). Other than information regarding interviewee's employable skills and work experience, the candidate's communication skills, engaging expression of work desire and good display of stance and evaluation also play an important role during job interview (Fox \& Spector, 2000; Schuh, 1973; Sheith Khidhir Abu Bakar; 2018).

Good interpersonal communication skills during the job interview may lead the candidate has the better chance to succeed in the interview (Prazak, 1969; Singh 2008). The importance of interpersonal interaction (Halliday, 2014) during job interview, however, has been reported under such global and conceptual terms as communication strategies. Thus, it is necessary to undergo a linguistic turn to linguistically evidence how the functions in job interview interactions (Tomilson, 2017; Zulita Mustafa, 2018).

Interaction between the interviewer and interviewee become uneven where more decisions is on the interviewer side compare to the interviewee (Singh, 2008; 2018). Thus, the interaction determinates and build the relationship of this genre makes it interactional practice that interviewer asks more questions whereas interviewee gives more personal statement in an expectedly prompt and cooperative manner. In addition, allowances for politeness strategy and cooperative principle for both interviewer and interviewee is important in a job interview conversation because they ought to display an amiable and cultivated image of the company and individual respectively (Stewart, 2010; Singh 2008; Truman, 2011; Zanmanian \& Anari, 2014). Therefore, the purpose of this study is to investigate the use of appraisal system-attitude and cooperative solidarity principle and also the perception of interviewees and interviewer of the job interview interactions.

\section{Literature Review}

System and generic structure (Martin \& White, 2005) under Systemic Functional Linguistics (SFL) and politeness theory and cooperative solidarity principle in pragmatics domain are applied for this study analysis. In addition, the study sets out to make an analysis of the interpersonal and pragmatic meaning and force of interaction in job interview interaction. It attempts to figure out the way for attitudinal evaluation and generic structure help build solidarity between the interviewer and interviewee and the way for the interactants give respect to cooperative solidarity principle.

\section{Appraisal System}

Previous studies reported that language in use serves along "autonomous" and "interactive" planes of discourse or "ideational" and "interpersonal" meanings (Sinclair, 1981; Halliday \& Matthiessen, 2004). Ideational serve as the representation of information and ideas communicated. Interpersonal meaning plays an important role in facilitating the delivery of the message and building solidarity between participants as well as serve as "a continuous motif or colouring" to ideas communicated throughout discourse and "the effect is cumulative" (Halliday, 1979, pp. 66-67). Martin (2000; 2005) developed the appraisal system which serve as a set of semantic attitudinal resources of interpersonal meaning, which help to track down linguistically how participants give their stance and evaluation, engage the other and build solidarity (Hunston \& Thompson, 2000; Martin \& White, 2005).

Appraisal system is achieved by three categories: 'engagement', 'attitude' and 'graduation' (Martin, 2000; Martin \& White, 2005). Engagement concerns how participants position towards sourcing facts and opinions, open or close discourse space and negotiate with each other, so it is not appropriate for this study to incorporate engagement resources as the communicative purposes of a job interview is not to negotiate on sourcing facts and ideas (Martin \& White, 2005).Attitude is concerned with speakers' affective reactions, judgments and evaluation of behaviour and things, which in this study are pertinent to the interviewee's own ability and work experience as well as the target company and the interviewer's comments on the interviewee's background and performance. Graduation shows the ways that speakers intensify or weaken their attitudinal and epistemic evaluations. For the purpose of the 
DOI: https://doi.org/10.47405/mjssh.v5i4.388

study, the job interview data has been collected from the real setting, and due to the extensive and authentic of the data. Therefore, the current study will be focused on the attitude sub-system of appraisal system. See Figure 1.

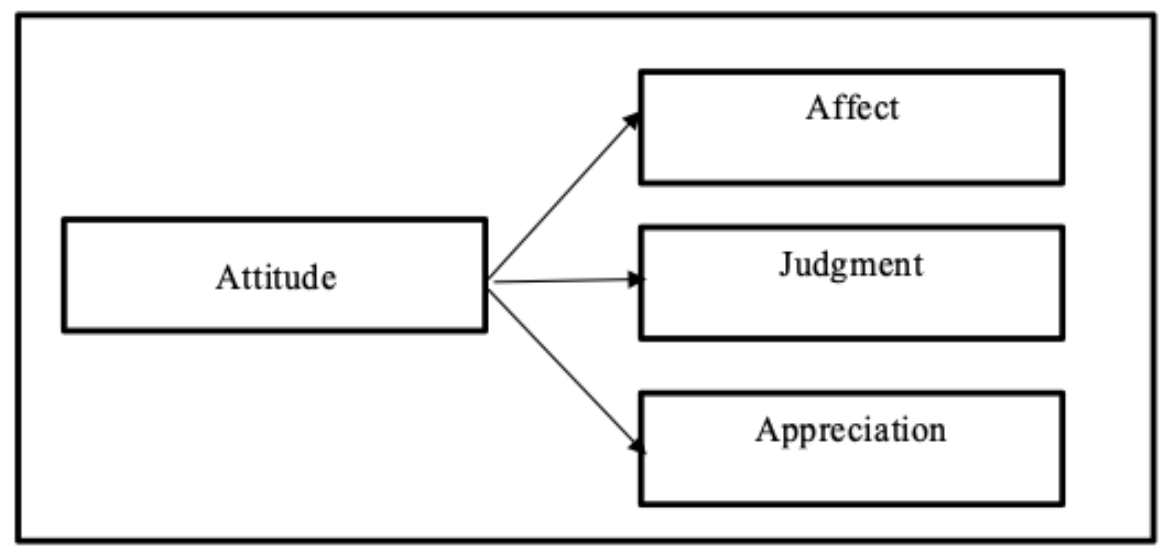

Figure 1: Appraisal Theory of Sub-system of Attitude

Figure 1 shows the sub-system of attitude of appraisal system theory which is divided into three categories namely; affect, judgment and appreciation. According to Martin and White $(2000 ; 2005)$, affect describes personal emotions such as happy, sad, anxious, angry and bored. Judgment describes to evaluate one's behaviour, character or ethics such as frank, honesty and helpful and appreciation refers to one's positive and negative qualities such as lovely and excellent for positive whereas negative horrible and weak. Martin and Rose (2007) have pointed that the attitude-subsystem could be one of the important tool to analyse spoken interaction especially when two-people involved in the interaction. This is supported by the study of Mohd Noor, Md Tab and Kamarulzaman (2017) that attitude subsystem could be one of the best tool to apply in analysing the attitude of interviewees in job interviews. From the findings of Noor, Md Tab and Kamarulzaman's (2017) study, they found definition of for appreciation, affect and judgment based on the job interview context. See Table 1.

Table 1: Definition of Appreciation, Affect and Judgment

\begin{tabular}{ll}
\multicolumn{1}{c}{ Attitude Subsystem } & \multicolumn{1}{c}{ Definition } \\
\hline Appreciation & $\begin{array}{l}\text { Interviewees focus interviewer on themselves and convince } \\
\text { the interviewer of their qualities in the interview } \\
\text { conversations. }\end{array}$ \\
affect & $\begin{array}{l}\text { Interviewees point out their capabilities and create a positive } \\
\text { impression on the interviewers. } \\
\text { Judgment }\end{array}$ \\
\hline
\end{tabular}

Source: Noor, Md Tab and Kamarulzaman (2017)

Table 1 shows the definition of appreciation, affect and judgment based on the study by Noor, Md Tab and Kamarulzaman's (2017). They also mentioned that this definition could be interrogated any studies pertaining to job interviews. Therefore, as for the purpose of the study, the definition will be used to see the emergence from the data.

\section{Past studies on Appraisal System and Workplace}

Eggins (2004) in the Systemic Functional Linguistics introduced his earliest framework on job interviews and employability between employers' attitude towards spoken occurrences in appointing a staff. There were also studies done by Alias, Sidhu, and Fook (2013b), Bye (2011), Hall, Gradt, Goetz 
and Musu-Gillette (2011) pertaining to aptitude and spoken based on English language proficiency in job interviews between interviewer and interviewee.

Studies have also done in local and as well as abroad by Rasul, Ismail, Ismail, Rajuddin and Rauf (2010), Sapaat, Mustapha, Ahmad, Chamili \& Muhamad (2011), Rafikul Islam and Mohamad Shukri (2013), Rasul Mohamad Sattar, Rose Amnah Abd Rauf, Azlin Norhaini Mansor, Ruhizan Mohamad Yasin and Zamri Mahamod (2013), Sabrena, Susan, Lawrence and Jeff (2013), Sarah Rahim (2017) and Davies, Fidler and Gorbis (2020). These studies were conducted with similar objectives in evaluating perception of employability skills of fresh graduates in different sectors and as well getting perceptions from human resource managers on the performance of these fresh graduates in job interviews. The findings found that interaction between interviewer and interviewee plays an important role in getting a job. In the present study, positive politeness and cooperatives are integrated for the purpose of the study.

\section{Cooperative Solidarity Theory}

Cooperative Solidarity theory was initially derived from the idea of politeness (Brown \& Levinson, 1978). Brown and Levinson (1987) pointed that the politeness theory was based on the people pertaining to the self-image which was also known as face. It is necessary to keep aware of our listeners, 'face' work is one of the most important considerations when we are in conversations. Further "face" is the public self-image which is emotionally invested but it can be lost, maintained or enhanced even everyone intends to claim and preserve for himself (Brown \& Levinson, 1987). Thus, face work should be persistently attended to exhibit and behave politeness in job interview conservation.

Besides, Grice (1975) revealed that there is a general cooperative solidarity guiding interactants and conversation provided all participants are cooperative, which makes interaction go smoothly. A study was done on investigation on how the two interactants cooperate in this sense by analysing their answers and responses which in line with Grice (1975) maxims of Quantity, Quality, Relevance and Manner subsumed to Cooperative Principle. Pragmatics interpretation has been criticized for its dependence on analysts' subjectivity (Parret, 1983; Smet \& Verstraete, 2006), but validity and reliability can be reduced if the pragmatic identification and interpretation proceeds systematically throughout the whole chunk of language. Thus, recognition and explication of these pragmatic features in a systemic way was carried out throughout the job interview in this study.

Martin (2000) and Martin and White (2005) and Brown and Levinson (1978) have provided the definitions of the theory as well as the categories. See Table 2.

Table 2: Definitions and Sample Occurrences of Appraisal System and Positive Politeness and Cooperative Solidarity

\begin{tabular}{ccc}
\hline Theories & Definitions & Sample Occurrences \\
\hline Appraisal System-Attitude & &
\end{tabular}

Affect

Judgement

\section{Affect deals with emotional I would love to have you reaction \\ How bad the accident was? \\ (Eggins \& Slade, 1997}

Refers to evaluate character and behaviour or ethics.
' $I$ am independent and reliable'

(Eggins, 2004) 
I am in love with my studies and some I feel exhausted with my assignment.

(Martin \& White, 2005).

\begin{tabular}{|c|c|c|c|}
\hline \multirow[t]{4}{*}{$\begin{array}{l}\text { Cooperative } \\
\text { Principle }\end{array}$} & Solidarity & $\begin{array}{l}\text { Refers to self-image which is } \\
\text { knows as a face image. }\end{array}$ & Interviewer: \\
\hline & & & $\begin{array}{l}\text { "How did you know about our } \\
\text { company?" }\end{array}$ \\
\hline & & & and the interviewee answered \\
\hline & & & Interviewee: "I got to know \\
\hline
\end{tabular}

Source: Martin and White (2000; 2005) and Brown and Levinson (1987)

Table 2 shows the definition of the categories of the theory and sample occurrences extracted from the previous studies. These definitions were helpful for the researcher to extract the occurrences from the spoken data. As for the sample occurrences, it was used to verify the extracted occurrences for the present study.

Based on the previous studies, it was found that there is still lacking in conducting studies in evaluating how the interaction between interviewer and interviewee are taken place to suggest the appraisal system and cooperative solidarity principle theory may help to smooth the interaction between interviewer and interviewee.

\section{Methodology}

\section{Theoretical Framework}

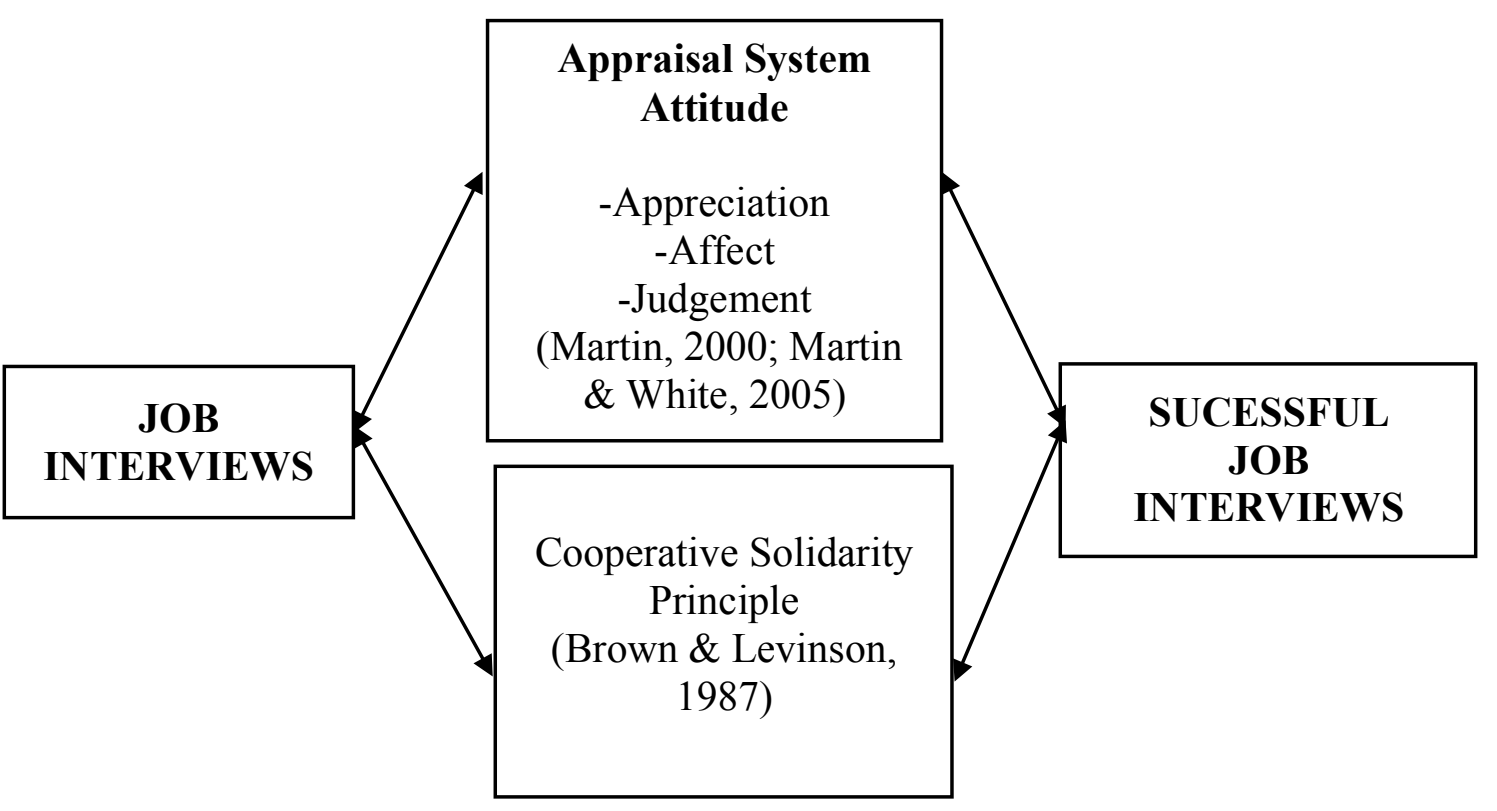

Figure 2: Overview of Theoretical Framework 


\section{Data Collection}

\section{Setting}

Written consents were obtained from the institution as well as the interviewees with terms and conditions. This institution provides diploma courses in Kuala Lumpur, Malaysia. This institution has been chosen based on the willingness as getting job interview data in Malaysia is private and confidential and not easy to access to this type of spoken data. The institution provides only four diploma courses namely: accounting, management, human resource management and business management and the courses are provided in full time basis for two years. These courses cater for those students who passed SPM with grade B in Bahasa Melayu (BM), English and Mathematics.

\section{Sampling}

There were 20 diploma final years students participated in the present study. The interviewees were chosen based on the willingness (Creswell, 2014). They were full time students and from the various courses as mentioned earlier. These students were also waiting for a degree enrolment in the public universities and the waiting period was almost a year. As they were waiting for the enrollment, the institution created job opportunities. The institution requested interested students to submit their resume. The resume will be given to the organisation for the shortlist process. Once it has done, the organisation will arrange the job interview with the institution. The job interview was done by one of the experts from out sourcing organisation which deals with customer services. The vacancy mainly on customer services and dealing with customer complaints and other related issues on products. The vacancy only for ten candidates. There were two processes involved in the job interviews especially for diploma students. The first section was a job interview, the second was training on job matter. The trainings will be conducted for two days and this is followed by an assessment pertaining to the training. If the candidates are passed the assessment, they are employed if they agree with the remuneration. Further trainings on job matters are provided if the candidates are selected.

\section{Data Collection and Analysis Procedures}

The present study employed a qualitative method (Creswell, 2014). The data collected and analysed into three phases.

The first phase was a job interview recording. The interviewer used the organisation's standard interview questions. The questions consist of 10 standard interview questions. However, only a few selected questions were used randomly based on the responses from the interviewer. The recording session was carried out for 10-12 mins for each participant. The interview data recorded and transcribed without using any notation transcription notation symbols. This is because the present study was not focus on conversation analysis. Therefore, transcription notation symbols were not required. After the transcription, the data were coded according to the categories namely; appraisal system and positive politeness and cooperative solidarity based on the definitions by the scholars, see Tables 1 and 2. A verification process on transcription and coding was done by three post-doctoral researchers from the field of languages and linguistics. An abbreviation is used ST-Student and IR-Interviewer for analysis purpose.

The second phase was semi-structured interview. A self-administered questionnaire was prepared by the researcher. The questionnaire consists of two sections. Section A on demographic and section B pertaining to the job interviews which consists of 11 questions. As for semi-structured interview, the recording was not allowed with the interviewees as requested by the organisation. A content validity was done on the questionnaire by three experts. Two experts from the field of human resource management (specialised in job interviews) and one expert, a staff from career and development services from the institution. These three experts made an agreement more than $90 \%$ of the questionnaire as Miles, Huberman and Saldana (2014) suggested that inter-rater reliability (IRR) is required in the qualitative. Li (2002) and Wodak (2013) noted that, with the IRR, even a sample is extracted from any written text extract or an excerpt of spoken represents the entire study based on the 
objective of the study. Therefore, in the present study, only two or three sample of excerpts used for the analysis.

The third phase was an in-depth interview with the interviewer. This in-depth interview was done on the interviewer to triangulate the present study. The question was probe based on the answers from interviewer. Therefore, there was no in-depth questionnaire was prepared as Miles, Huberman and Saldana (2014) noted that for the in-depth a specific set of interview questionnaire may not be required.

\section{Analysis and Discussion}

The analysis sections were divided into four sections. Section 1 provides the background of the interviewees, section 2 on general structure, section 3 on analysis on appraisal theory, section 4 on positive politeness and cooperative solidarity, section 5 on semi-structured interviews with the interviewees and section 6 on in-depth interview with the interviewer.

\section{Background of the Interviewees}

Table 3 provides the profile background of the interviewees. Their names were used as pseudonym as a Student 1 . Most of the interviewees from the course of diploma in human resource management and diploma in management. There was no participant from diploma in accounting. It was found that most of the students from diploma in accounting are not interested any jobs related to the customer services. They preferred most to be accounting job in the office or auditing firms.

Table 3: Background of the Interviewees

\begin{tabular}{|c|c|c|c|c|}
\hline NO & NAME & AGE & GENDER & COURSE \\
\hline 1. & Student 1 & 18 & $\mathrm{M}$ & Diploma in Management \\
\hline 2. & Student 2 & 18 & $\mathrm{~F}$ & Diploma in Business Management \\
\hline 3. & Student 3 & 19 & $\mathrm{~F}$ & Diploma in Human Resource Management \\
\hline 4. & Student 4 & 19 & $\mathrm{~F}$ & Diploma in Management \\
\hline 5. & Student 5 & 17 & $\mathrm{~F}$ & Diploma in Human Resource Management \\
\hline 6. & Student 6 & 19 & $\mathrm{~F}$ & Diploma in Management \\
\hline 7. & Student 7 & 18 & $\mathrm{~F}$ & Diploma in Accounting \\
\hline 8. & Student 8 & 19 & M & Diploma in Human Resource Management \\
\hline 9. & Student 9 & 20 & $\mathrm{~F}$ & Diploma in Management \\
\hline 10. & Student 10 & 20 & $\mathrm{M}$ & Diploma in Human Resource Management \\
\hline 11. & Student 11 & 19 & $\mathrm{~F}$ & Diploma in Human Resource Management \\
\hline 12. & Student 12 & 19 & M & Diploma in Management \\
\hline 13. & Student 13 & 20 & M & Diploma in Management \\
\hline 14. & Student 14 & 20 & $\mathrm{~F}$ & Diploma in Human Resource Management \\
\hline 15. & Student 15 & 20 & M & Diploma in Management \\
\hline 16. & Student 16 & 20 & M & Diploma in Human Resource Management \\
\hline 17. & Student 17 & 20 & $\mathrm{~F}$ & Diploma in Human Resource Management \\
\hline 18. & Student 18 & 19 & $\mathrm{~F}$ & Diploma in Human Resource Management \\
\hline 19. & Student 19 & 19 & M & Diploma in Human Resource Management \\
\hline 20. & Student 20 & 19 & $\mathrm{M}$ & Diploma in Management \\
\hline
\end{tabular}

\section{Analysis on General Structure}

Job interview was started with the general structure by four movements namely confirmation, warmup, information exchanged and wrap up. All these movements were tallied with asking permission to enter to the interview room till saying thank you which is tallied with the standard question questions. The sample occurrences are provided in Table 4. 
Malaysian Journal of Social Sciences and Humanities (MJSSH), Volume 5, Issue 4, (page 56 - 70), 2020

DOI: https://doi.org/10.47405/mjssh.v5i4.388

Table 4: Sample Occurrences of the Four Movements

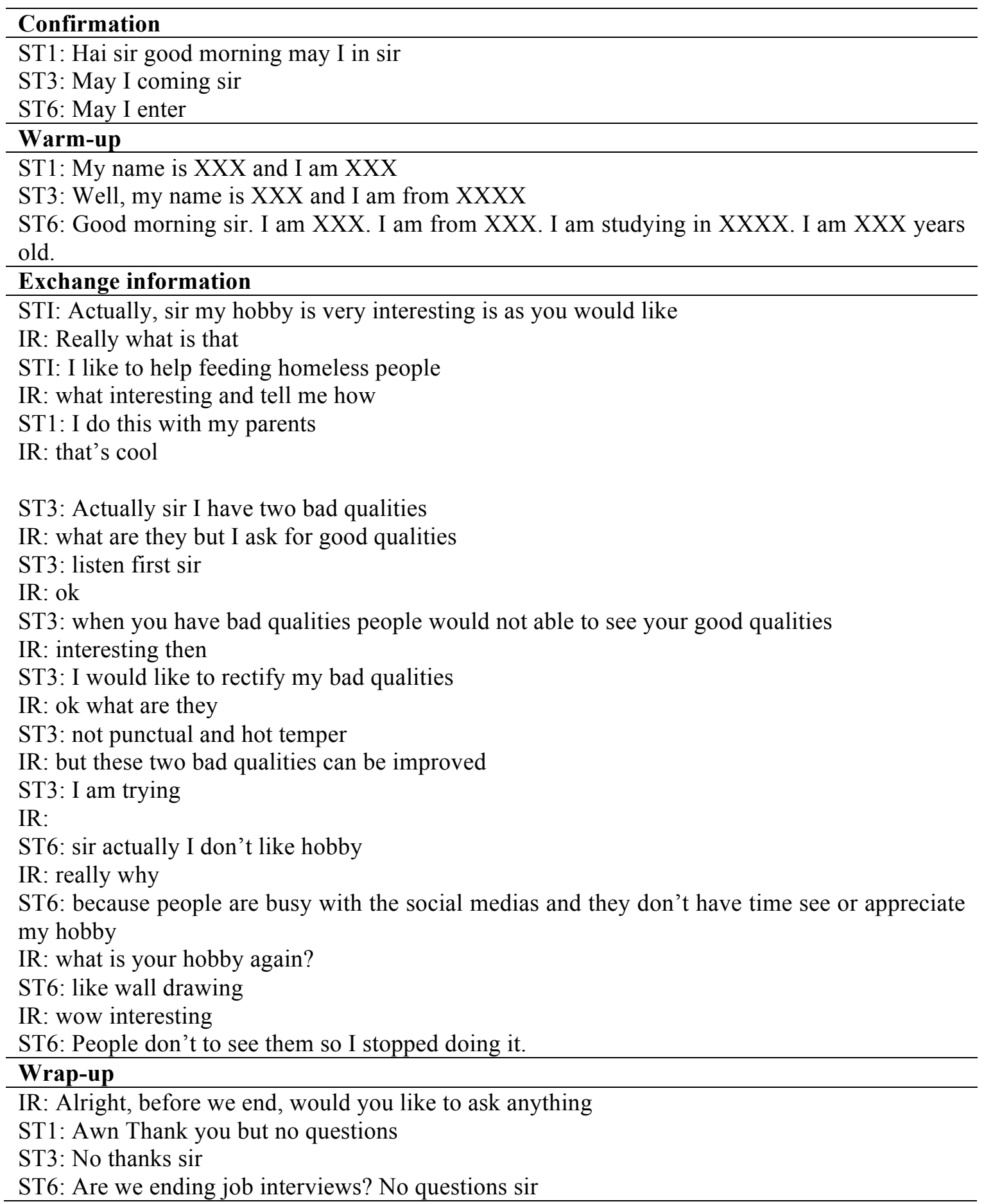

The sample occurrences are conducive to the present study in structing the job interview as there are no specific procedure to conduct job interviews as long as compliance with these four movements. The sample occurrences are consensus with the findings of Canavor and Meirowitz (2010) that all these moved are essential moves in a hiring process and it should be covered in the standard interview questions.

\section{Analysis on Attitude Sub-System}

Table 5 provides the sample occurrences of affect, judgment and appreciation. In the category of affect interviewees point out their capabilities and create a positive impression on the interviewers. As for the judgement, the STs 9 and 11 convince the interviewer that s/he could be a good example to others. STs 
13 and 20 were able to express that they are decently positive as in behaviour in being hardworking in their task with comprehensive information. Whilst ST13 and ST20 also expressed in a different manner that ST13 was able to listen to complaints alone is a positive trade. Likewise, ST20 was able to solve the matter yet s/he need assistance to solve the issues. In relation to appreciation, ST2, ST6, ST16 and ST17 were able to convince the interviewer by portraying good qualities. ST2, ST6, ST16 and ST17 have expressed well on their qualities on handling different task in previous jobs. They have shown their qualities of adaptability and change in environment. ST2 and ST16 reaction were to be flexible in the current company on accepting any tasks. However, response on the likeness or challenges that they may go through. The above finding is supported by the finding by the study of Noor, Md Tab and Kamarulzaman (2017) that these students would be able to cover all these the sub-system of attitude. However, due to poor English language proficiency, they limited their utterances. The job interview was smooth due to the attitudes of both the interviewer and the interviewee. The answers fit perfectly with the questions asked. This is a way to observe the many different techniques used in SFL terms.

Table 5: Sample Occurrences of Affect, Judgment and Appreciation

\begin{tabular}{ll}
\hline Affect & ST2: I have skills and I think I can and I am good at balancing myself and \\
able to handle many task \\
ST5: During my school time, I was able to complete many jobs assigned my \\
teachers. \\
ST7: I can speak well \\
ST9: My SPM result was good \\
ST9: I was able to outline the schedule and arrange to the project \\
ST11: Sir I rajin tau (diligent) to do the work. \\
STI3: I entertain complaints \\
ST20: I could solve the matter but I may need help \\
ST2: I could handle challenge and willing to face the changes. \\
Appreciation & ST6: I can take up any jobs sir. \\
& ST16: I can perform well and I am confidence in what I am doing. I can \\
& handle customer. \\
& ST17: I can make my own sensible decision.
\end{tabular}

\section{Cooperative Solidarity Principle}

Table 6 provides the sample occurrences of cooperative solidarity principle. IR asked how did you know about the company. STs 2, 4,6 able to provide sufficient information whereas ST10 provided detailed information by showing that ST10 was really wanted to get detailed information as this was happened in the exchanged movement. The finding of this study is consensus in the finding of Jiang (2013) that job interview interaction was carries out smoothly which can be attributed to cooperation principle solidarity. Whilst the interviewer also upheld the cooperation principle solidarity which manifest the question is closely important in the exchange movement.

\section{Table 6: Sample Occurrences of Cooperative Solidarity Principle}

IR: Did you research or how did you know about the company?

ST2: I got to know through the Facebook and I found your organisagtion is an esteem organisation.

ST4: I found some information from the website and would be understand the nature of your company.

ST6: Ah..I found from the notice board then I searched for more detailed information on website.

ST10: Sir, I found this information from the notice board. I was also eager to call your company to find out more when I call the phone engaged. So I decided to search facebook and I found the information. It was very useful information. 
DOI: https://doi.org/10.47405/mjssh.v5i4.388

\section{Semi-Structured Interviews with the Interviewees}

Based on the semi-structured interviewees. There were four major issues were discovered and they relatively relevant to the objective of the study. The first was most of the interviewees were not able to understand the questions. The sample occurrences are provided in Table 7.

Table 7: Sample Occurrences Showing Unable to Comprehend the Questions

IR: what you intend to do in five years' time?

ST1: Ah la..sir...I didn't understand your question/

IE: I would like to know what would you like to do for the company in five-year time?

STI: oh ok

IR: What good qualities do you have?

ST3: what sir?

IR: Your best qualities?

ST3: Tak faham sir

IR: Would you like to help people around you? And how?

ST3: oh ok

Please repeat

IR: Are you fit for the position you are applied even though you do not have working experience?

ST6: Encik, your question is too long, and I could not understand or say it again

IR: OK

ST6: You mean how sure I am to apply for the post and how I do work withour working experience?

IR: sort of

IR: How do you describe your good qualities?

ST8: Say it again

IR: Your beautiful qualities, such a good leader, good at talk to people

ST8: oh ok...

The above occurrences show that the interviewees were not able to understand the questions. Therefore, they requested the interviewer to repeat the questions. The interviewer has to give some examples in order to answer the questions.

The seconds was most of the interviewees did not attend any job interviews. The sample occurrences are provided in Table 8

Table 8: Sample Occurrences did not attend Job Interviews

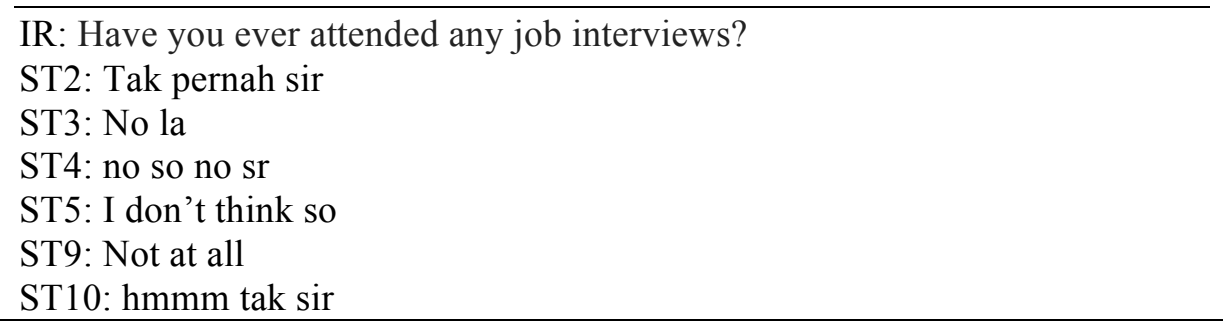

The above occurrences show that most of the interview had not experienced attend job interviews. The above occurrences consensus with the interviewees as they straight continued their studies of the school. Therefore, there was no chance for them to attend job interviews.

The third is followed by another question "How did you feel during the job interview?". The sample occurrences are provided in Table 9. 
DOI: https://doi.org/10.47405/mjssh.v5i4.388

Table 9: Sample Occurrences How did you feel during the job interview

IR: How did you feel during the job interview?

ST1: oh sir...you know what I don't feel excited at all

IR: How did you feel after attending the job interview?

ST2: hmmm takut (afraid) sir

IR: How did you feel after attending the job interview?

ST3: sir...takut (afraid) la

IR: How did you feel after attending the job interview?

ST4: I am panic

IR: How did you feel after attending the job interview?

ST5: nervous tau

IR: How did you feel after attending the job interview?

ST6: sir...I almost panic

IR: How did you feel after attending the job interview?

ST7: nervous

IR: How did you feel after attending the job interview?

ST8: ooo I nak pengsan sir (unconscious)

IR: How did you feel after attending the job interview?

ST9: anxiety sir

IR: How did you feel after attending the job interview?

ST10: stress sir

IR: How did you feel after attending the job interview?

ST11: hahaa anxious sir

The above occurrences evidently showed that 20 interviewees were feeling nervous and anxious during the job interviews. This could be one of the reasons why they were not employed. This may impact to utter and not able to interact well during job interviews. As a result, proper interactions were not able to carry out between interviewer and interviewee. The fourth was "Did you have any difficulty in introducing yourself in the beginning of the interview?".

The sample occurrences are evidently shown that most of the interviewees had difficulty in answering the self-introduction question. The sample occurrences are provided in Table 10.

Table 10: Sample Occurrences on self-introduction

IR: Please introduce yourself

ST2: My name XXX and I am studying...

ST3: Sir, my name is XXX. I am from XXX. I am XXX years old. That's all.

ST6: I am XXX years old and then my name is XXX. I hope you know me better from the resume.

ST7: I am from XXX. I would like to introduce myself.

ST10. Saya XXX. I am from XXX. That's all.

Table 8 shows sample occurrences on the self-introduction. IR asked those interviewees to introduce themselves. Most of the interviewees answers in short answers literally they used subject + verb + Object which is simple sentence and there was no longer utterance. This shows they are lacked of English language proficiency. 


\section{In-Depth Interview}

Based on the in-depth interview with the interviewer, it was found that most of the interviewees were not able to understand the questions such as what you intend to do in five years' time, are you fit for the position you are applied and describing specific qualities. They were a few sample occurrences show that they did not understand those questions by uttering e.g. 'I didn't understand your question', 'tak faham la sir (I didn't understand)', 'please repeat' and 'say it again'. This reveals that they were not exposed to the standard interview questions. Apart from that, nervous and anxious feeling were one of the challenges for the interviewees. They were out of focus due to these feelings. The above finding is similar by the finding of Sarah Rahim (2017) and Davies, Fidler and Gorbis (2020) that those interviewees who had not exposed to job interview process were shown nervous and anxious feelings. The interview also suggested that class room practice in job interviews is required in order to dwindle these feelings. The outcome of the job interview was among the 20 interviewees, only 3 were selected for the second interview.

\section{Implication of the Study}

The findings of the study might be useful for the public and private institutions to prepare undergraduate for a job interview. It should not be focused on degrees students only; diploma students should be focused too. Most of the public universities, private colleges and universities prepare course modules for job interviews as well as writing resume and application letter. More emphasises should be devoted into English language, familiar with standard interview questions and required employability skills for the initial stage of workplace. Studies done by Rasul, Ismail, Ismail, Rajuddin and Rauf (2010), Rahmah Ismail, Ishak Yussof and Lai (2011), Rafikul Islam and Mohamad Shukri (2013), Siti Zaidah Zainuddin, Pillai, Perlag and Phillip (2019) and Davies, Fidler and Gorbis and (2020) noted that what are the employability skills need to be shown in order to be met the probation period during an employment.

Requesting an expert to interview which is good. However, the experts could also conduct a training to train the lecturer of the institution to educate the students by doing a mock interview. It is much debated that experts are required in evaluating one's ability. Nevertheless, it causes panic or anxiety for the students during the job interviews. If a familiar face conducts an interview, they may talk freely as the students are still in the beginning stage. This is because to reduce the anxious during the job interview so that they could perform well.

Further, higher learning institutions should develop a curriculum on the job interview by having specific learning outcomes. This should be standardised nationally which would be benefited to our students. And this curriculum should be implemented in the school so that students would know and cultivate the readiness for job requirements from the school itself and this is also followed by emphasising on English language usage and as well the generic structure of four movement in school which be helpful in the future especially in job interviews.

Pre and post job interviews should be done. A mock job interview should be conducted without any training and it has to be recorded. Based on the outcome of pre-job interviews, a proper training should be conducted by showing their own videos and compare to sample video clips on job interviews, practice and familiar with the standard interview questions. Then, post job interviews should be conducted in comparing pre and post job interview outcome to have a better picture in job interview.

\section{Limitations of the study}

This study is limited to a few caveats. The first, number of sampling is relatively small but for a qualitative study the sampling is accurate. However, more interviewees would be more significant as some interviewees nervous and anxious during the interviews. This may impact to fulfil the objective of the study. The second, the interviewees did not agree for a video recording as the researcher could 
analyse the non-verbal behaviours of the interviewees during the job interviews. The third, the place is also not suitable as many students were around in the premise and had difficulty in recording as the recording was done during the class time or else the interviewees were not able to participate as they were full equipped with the classes. The fourth limitation was the interview did not mention to the researcher which interviewees who particularly selected, keep in view (KIV) and rejected due to the terms and conditions. Therefore, the present study was not able to provide the list of selected, KIV and rejected for a job.

\section{Conclusion}

To sum up, the findings show the generic structure, engagement, attitude and graduation, positive politeness and cooperative solidarity imparted the knowledge and preparing students for job interviews. The students should prepare themselves to workplace and need to understand the employability skills and how these employability skills would mold the work performance. The findings support the current theories of appraisal system-attitude and cooperative solidarity principle in job interviews. The present study applies this theoretical to the employment world and display interviewer could unwittingly adopt the job interview would be evaluated by using these theories. Although the findings of the present study are theoretically reliable Martin (2000), Martin and White (2005) and Brown and Levinson (1987) that could be an eye opening to those in outsourcing industries. Further study can be done by looking at impression management tactics and integrated with linguistics components to contribute significantly for higher learning institutions in developing or injecting a new tool for job interviews.

\section{References}

Alias, M., Sidhu, G. K., \& Fook, C. Y. (2013b). Unemployed Graduates' Perceptions on their General Communication Skills at Job Interviews. Procedia - Social and Behavioral Sciences, 90(0), 324333. doi: http://dx.doi.org/10.1016/j.sbspro.2013.07.098

Bye, H. H. (2011). Personal Values and Intended Self -presenttion during Job Interviews: A cross Cultural Comparison. Applied Psychology, 60(1), 160-1982.

Brown, P., \& Levinson, S. (1978). 1987. Politeness: some universals in language usage.

Canavor, N., \& Meirowitz, C. (2010). How to Interview Effectively: Pearson Education.

Creswell, J. (2014). Research design: Qualitative, quantitative, and mixed methods approaches (4th ed.) SAGE Publications, Inc.

Davies,A., Fidler,D. \& Gorbis,M. (2020). The polarisation of job Opportunities in the US labour market. Center for American Progress and The Hamilton Project.

Eggins, S., \& Slade, D. (1997). Analysing Casual Conversation. London: Equinox Publishing.

Eggins, S. (2004). An Introduction to Systemic Functional Linguistics (2nd edition ed.). Manchester: Continuum.

Fox, S., \& Spector, P. E. (2000). Relations of emotional intelligence, practical intelligence, general intelligence,

Grice, H. P. (1975). Logic and conversation. 1975,41-58.

Halliday, M. A. K. (1979). Modes of meaning and modes of expression: types of grammatical structure, and their determination by different semantic functions. Function and context in linguistic analysis: A Festschrift for William Haas, 57-79.

Halliday, M. A. K., \& Matthiessen, C. M. (2004). An introduction to functional grammar.

Hall, N. C., Gradt, S. E. J., Goetz, T., \& Musu-Gillette, L. E. (2011). Attributional Retarining,SelfEsteem, and the Job Interview:Benefits and Risks for college Student Employment. The Journal of Experimental Education, 79(3), 318-339.

Hausknecht, J.P., Day, D.V., \& Thomas, S.C. (2004). Applicant reactions to selection procedures: An up dated model and meta-analysis. Personnel Psychology, 57,639-683.

Halliday, M.A. K. (2014). An introduction to functional grammar. London: Edward Arnold.

Hunston, S., \& Thompson, G. (2000). Evaluation in Text: Authorial Stance and the Construction of Discourse: Authorial Stance and the Construction of Discourse. Oxford University Press. 
Martin, J. R., \& White, P. R. R. (2005). The Language of Evaluation: Appraisal in English. New York: Palgrave Macmillan.

Martin, J. R., \& Rose, D. (2007). Working with Discourse: Meaning beyond the clause (2nd ed.). London: Continuum.

Martin, J. R. (2000). Beyond exchange: Appraisal systems in English. Evaluation in text, 142-175.

Martin, J. R., \& White, P. R. (2005). The language of evaluation: Palgrave Macmillan Basingstoke and New York.

Parret, H. (1983). Semiotics and pragmatics: An evaluative comparison of conceptual frameworks: JohnBenjamins Publishing.

Miles, M.B., Huberman,A.M. \& Saldana,J. (2014). Qualitative data analysis: A method sourcebook, (3rd ed.) Washington, DC: Sage Publications.

Mohd Noor, S.N.F., Md Tab, F. \& Kamarulzaman, R. (2017). Exploring job interview skills of future engineers: Application of appraisal analysis assessment and verbal impression management. Journal of Technical Education and Training, 9(1), 87-99.

Prazak, J. (1969). Learning job-seeking interview skills. Behavioral Counseling, 414-424.

Rafikul Islam \& Mohamad Shukri. (2013). Enhancing graduates' employability skills: A Malaysian case. Retrieved June 12, 2016, from http://irep.iium.edu.my/28680/1/Rafikul_Malaysia.pdf

Rahmah Ismail, Ishak Yussof \& Lai, W.S. (2011). Employers' Perceptions on Graduates in Malaysian Services Sector. International Business Management, 5 (3), 184-193.

Rasul, M. S., Ismail, M. Y., Ismail, N., Rajuddin, M. R., \& Rauf, R. A. A. (2010). Development of employability skills assessment tool for manufacturing industry. Journal of Mechanical, 30, 461.

Rasul Mohamad Sattar, Rose Amnah Abd Rauf, Azlin Norhaini Mansor, Ruhizan Mohamad Yasin \& Zamri Mahamod. (2013). Graduate employability for manufacturing industry. Procedia-Social and Behavioural Sciences, 102, 242-250. doi:10.1016/j.sbspro.2013.10.739

Rizvi, S. Teckchandany, S. \& Ahuja, G. (2013). A study of competencies and skill sets needed by potential recruiters in the financial sector for management graduates. Management Dynamics, 13 (1), 54-69.

Sapaat, M. A., Mustapha, A., Ahmad, J., Chamili, K., \& Muhamad, R. (2011). A data mining approach to construct graduates' employability model in Malaysia. International Journal of New Computer Architectures and Their Applications (IJNCAA), 1(4), 1086-1098.

Sabrena R. P, Susan, A. S., Lawrence, A.H \& Jeff, L. (2013). Employment interview outcomes and speech style effects. Journal of Language and Social Psychology, 21(2), 144-161.

Siti Zaidah Zainuddin, Pillai, S., Perlag, F.D. \& Phillip,P. (2019). English languageand graduate employability, Education and Training, 61(1),79-93.

Singh, G.K.G. \& Singh, S.K.G (2008). Malaysian graduates' employability Skills. UNITAR EJournal, 4 (1),11-44.

Singh, R. (2018, January 22). Language main barrier to grads getting jobs. The Sun Daily. Retrieved from http://www.thesundaily.my/news/2018/01/22/language-main-barrier-grads-gettingjobsupdated

Sarah Rahim. (2017, January 13). Gap year option: varsity students to get a year off from study. New Straits Times. Retrieved January 14, 2017, from http://www.nst.com.my/news/2017/01/203878/gap-year-option-varsity-students-get-year-study

Sarangi, S. \& Candlin, C. N. (2011). Professional and organisational practice: A discourse/communication perspective, 3-60. In C. N. Candlin and S. Sarangi eds., Handbook of Communication in Organisations and Professions. Berlin: Mouton de Gruyter.

Selvaratnam,V. (2018, August 28), Our glaring English deficiency is too big to ignore. Malaysiakini. Retrieved September 05, 2018, from https://www.malaysiakini.com/news/440643

Schuh, A. J. (1973). Effects of interview rating form content and rater experience on the evaluation of a job applicant1. Personnel psychology, 26(2), 251-260.

Sheith Khidhir Abu Bakar. (2018, January 18). Looking for jobs? Learn how to speak first. Free Malaysia Today Online. Retrieved January 18, 2018, from http://www.freemalaysiatoday.com/category/nation/2018/01/18/looking-for-jobs-learn-to-speakenglish-first-says-mef/

Sinclair, J. (1981). Planes of discourse. The two-fold voice: Essays in honour of Ramesh Mohan, 7089. 
DOI: https://doi.org/10.47405/mjssh.v5i4.388

Smet, H. D., \& Verstraete, J.-C. (2006). Coming to terms with subjectivity. Cognitive Linguistics, 17(3), 365-392.

Stewart, C. J. (2010). Interviewing: principles \& practices: Tata McGraw-Hill Education.

Tomilson, M. (2017). Forms of graduate capital and their relationship to graduate employability, Education + Training, 59(4), 338-352.

Truman, H. S. (2011). Management study of communication skills. Journal of Human Resource, 1(3), 11-32.

Wodak, R. (2013). Critical discourse analysis. London, UK; Sage.

Zulita Mustafa. (2018, July 11). Proficient way to be better English. New Straits Times. Retrieved July 12, 2018, from https://www.nst.com.my/education/2018/07/389562/proficient-way-better-e 